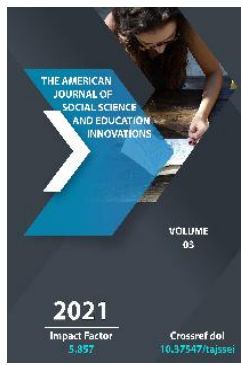

Journal Website: http://theamericanjour nals.com/index.php/taj ssei

Copyright: Original content from this work may be used under the terms of the creative commons attributes 4.0 licence.

\section{Fundamentals Of Change In Children's Psyche}

\author{
Khuseyn Avaskhonovich Zaytmetov \\ Candidate Of Psychology, Associated Professor, Head Of The Department Of Social And \\ Professional Psychology, Khujand State University Named After Academician Bobojonov Gafurov \\ Khujand, Tajikistan \\ Mansurboy Taimuratovich Lufov \\ Candidate Of Pedagogical Science, Senior Lecturer, Department Of Social And Professional \\ Psychology, State Educational Institution KSU Named After Acad. B. Gafurov Khujand, Tajikistan \\ Muqaddas Xoliqzoda \\ Candidate Of Pedagogical Science, Associated Professor, Department Of Theory And Methods Of \\ Preschool Education GOU, Khujand State University Named After Academician Bobojonov Gafurov \\ Khujand, Tajikistan \\ Naila Boboydavlat Qizi Davlatova \\ Student, Psychology And Preschool Education, Khujand State University Named After Academician \\ Bobojonov Gafurov Khujand, Tajikistan
}

\title{
ABSTRACT
}

In this article, we looked at the nature of children as a social phenomenon and the factors that change it. The analysis of the factors influencing human development has shown that among these factors, education and upbringing are important and leading.

\section{KEYWORDS}

Psyche, upbringing, knowledge, ethics, factor, influence, character, thinking, change.

\section{INTRODUCTION}

These days, in the self-government system, that is, in the neighborhood, the family is the social basis of society. Accordingly, the upbringing of a physically healthy, spiritually mature, morally pure and highly cultured young generation begins with the family. The 
family is the basic unit of life, the rehabilitation of the population, the upbringing of children. The main school of child rearing is the relationship between parents.

It is this family relationship, the development of culture that shows the young generations ideas, concepts, worldviews and oriental morals about the spiritual world, social life, and the right way to follow them. The spiritual image of the younger generation, their behavior and attitudes are first formed in the culture of family relations. Everyone, no matter how big or small, expresses their feelings, inner turmoil, dreams and hopes in the process of communication. In this regard, the President of the Republic of Uzbekistan Sh. M. Mirziyoyev said: “... the introduction of new modern methods of education, including information and communication technologies ..., the implementation of urgent tasks in this area is the future of our youth, society and our country is of strategic importance for." [1.44] is a clear proof of our opinion.

\section{THE MAIN FINDINGS AND RESULTS}

It is known that the idea of educating the childs psyche has both a national and universal character, and it is the path to perfection that leads mankind to spirituality and enlightenment, goodness and exaltation. It is for this reason that humanity has emerged that the issue of upbringing has become an important problem for individuals, families, communities, states, and they are implemented in many different ways, by different means and methods.

The development of the child and the power of his psyche and biological influence are not always the same. The reason is that a persons behavior, attitudes and relationships are influenced by his age, education, life experience, people and circumstances [2.48].

In order to correctly identify and evaluate a child's qualities, it is necessary to observe him in different situations of the relationship. Only then will the childs social behavior, spiritual image, human qualities and psyche be realized.

So, it is necessary to know the task and characteristics of the childs development. From kindergarten age onwards, we feel a change in the white spirit and the need to expand our mental capacity. Questions such as "Why?", "How" used in the childs language at this time, and reasonable and clear answers to them from adults are the mental functions that allow the child to improve cognitive processes: cognition, memory, thinking, attention, speech develops, expands the range of knowledge.

According to experts, in preschool, a child receives almost half of the information that is formed in the brain throughout life. In the third half of the developmental stage, the child begins to meet his social needs. Its about living in a community, having a place in the community, and being able to emphasize your "l" in it. This need begins when a three-yearold begins to use words such as "I" and "I am" in his language, and thus begins to feel separate from those closest to him. Such a change of heart is not easy for a child. That is why adolescence is characterized by a number of difficulties, whims, and aggressive behavior. 
During this time, the child begins to distinguish between punishment and encouragement, and tries not to be seen by the public without being punished in any way. That is why the good conditions created for the moral and spiritual upbringing of the child in the family and at school have a significant effect on his psyche during this period [3].

Adolescence is a leading educational activity in schools and other educational institutions in which the child, in addition to acquiring skills and abilities related to education, is also important as a person. "Adolescence is the most complex and thus important stage of development. Early adolescence includes 11-13 years, adult adolescence 14-15 years. The most important feature of this period is that it is the transition from childhood to adolescence is a period of transition from youth to adulthood. Adolescence is the stage of development of the organism. Early adolescence is important. Adolescence is characterized by rapid and uneven development of the body, during which the body and bones harden.

The Messenger of Allah (peace and blessings of Allah be upon him) said: In addition to honoring your child, improve his upbringing and manners. "[4.193]. At the same time, "No father can leave a better legacy to his child than manners"[5], defined the role of parents in upbringing. Every child who grows and develops is an object of education.

The development of the human child is an important process. It is known that a person changes physically and mentally throughout life. But in childhood, adolescence and adolescence, development is extremely powerful. It is during these years that the child develops as a person, both physically and mentally, as a result of the purposeful influence of upbringing, the child develops as a member of society and finds himself in a complex system of social relation takes its rightful place.

Upbringing is central to childrens socialization. Education means "pedagogy", which means "the science of child rearing", the laws of comprehensive education, the laws of harmonious development of each person at an early age [6].

Educators are like a doctor who, just as a physician treats a disease in the body of a patient, must educate the child to overcome the treatment of purity, from the treatment of good behavior to the center of anger in the body.

Well-known artist Pablo Picasso wrote at the age of 80: "The concept of age and old age only matters when one is spiritually old. At the moment, even though Im much older, I still feel like Im in my 20s. " That is, when a persons life is divided into certain periods, each stage of it is evaluated according to the value of the good deeds done by the person to himself and his relatives. Therefore, when a person studies a person, his development is important by knowing the age characteristics of this or that stage.

Regarding the upbringing and psyche of a child, Abdullah Avloni says: "For the health and happiness of a child, it is necessary to bring up a child well, to keep the body clean, to correct the profession from an early age, to nurture bad habits, to teach good manners" [5].

So far, the process of direct socialization with the process of educating the child's psyche 
has been studied together. Much attention has been paid to the study of the process of human socialization in stages. Several periodic schemes are also proposed. This is understandable, because a persons way of life and key moments change over the course of historical development.

John Bowley, a British writer and researcher on the organization of the problem of children's personality formation in the 1950s, said that children who are emotionally disconnected and have difficulty communicating with others say that children are unscrupulous. They believe that light manipulation is possible or that they cannot express their feelings sincerely.

Parents can say like that "Whatever we do for them, there is no result" [7.122]

Supporting and implementing different aspects of such childrens attitudes is a complex process. They dont care about others. They cannot give it to others because they have also attained compassionate love. They continue to live childish-egocentric, impulsive lives. They have problems enforcing laws and regulations. The first thing that interests them is, "Whats in it for me?" they do not trust others to such an extent that the behavior of such children is aimed at maintaining distance from others.

In such cases, parents should treat their children as friends.

For, as the great thinker Ibn Sina pointed out, a child should be treated like a king until the age of 7 , like a slave under the age of 14 , and like a friend until the age of 16 [8]. The views expressed by our encyclopedic scholars are still relevant today. "Spiritual education is based on morality and intelligence. The first is to cultivate good qualities, and the second is to protect others from evil. This means that upbringing can only be achieved if it is linked to both morality and human relations, to the values, traditions and customs that have proved their worth over the centuries" [9].

\section{CONCLUSION}

In conclusion, the best influence on a child's psyche is a book. To be a "decent person", a person has two opportunities: education and upbringing. Theoretical maturity is achieved through knowledge; and education is a way to create moral value and practical activity in communication with knowledge" [10]

Therefore, in our opinion, it would be expedient to follow the noble ideas of our wise people, thinkers, to study the most popular moral values applied to our youth by our ancestors from childhood and to use them as a factor in changes in the child's psyche.

\section{REFERENCES}

1. Mirziyoev SH. Critical analysis, strict discipline and personal responsibility should be the daily rule of every leader. Tashkent: “Uzbekistan”, 2017. - P. 44.

2. Inomova M. "Spiritual and moral upbringing of children in the family". Tashkent: 1999-yil. P. 48.

3. Family spirituality. Republic of Uzbekistan. Public Opinion Research Center. Textbook. Tashkent: -2007.

4. Al-Bukhari List of Al-Jame as-Sahih Hadiths. Tashkent: -2003, P. 193. 
5. Abdulla Avloni. Turkish gulistan or morality. Tashkent: 1996.

6. Yusupova P. "Pedagogy of preschool education". Tashkent "Teacher” 1993.

7. A.Childs Journey Thrugh Placement, London. V. Fahlbug.on page-122

8. www.ziyonet.uz

9. Yodgorov R., Gaybullayev N., Mamatqulova R. "Pedagogy". Tashkent: -2000

10. Abu Nasr Farobi. A city of noble people. Tashkent: Public Heritage Publishing House named after Abdulla Qodiri. 1993. 